\title{
Transmission electron microscopy of presumed sensory receptors in the forebody papillae of Crepidostomum metoecus (Digenea: Allocreadiidae)
}

\author{
Zdeňka Žd'árská and Jana Nebesářová \\ Institute of Parasitology, Academy of Sciences of the Czech Republic, Branišovská 31, 37005 České Budějovice, Czech \\ Republic
}

Key words: Trematoda, Digenea, Crepidostomum metoecus, forebody papillae, sensory receptors, transmission electron microscopy

\begin{abstract}
Five types of presumed ciliate sensory receptors were detected in the forebody papillae of the adult fish trematode, Crepidostomum metoecus (Braun, 1900). The cilia are short and submerged in a tegumental pit. The apical bulb part of all types of receptors observed is supported by a dense collar and connected to the tegument basal plasma membrane by a circular septate junction. In sensory receptors types I and III no rootlet is present; the bulbs of sensory receptors types III and IV contain an electron-dense formation.
\end{abstract}

In this study, data on the ultrastructure of sensory receptors localised in the forebody papillae are presented, which completes our transmission electron microscopy (TEM) studies (Žd'árská and Nebesářová 2002a, b, $2003 \mathrm{~b}$ ) on the forebody part of Crepidostomum metoecus (Braun, 1900). In a previous paper (Žd'árská and Nebesářová 2003b) only intra-tegumental sensory receptors of this species were described. In adult digeneans of the genus Crepidostomum, TEM studies of sensory receptors of muscular papillae are not available. In C. metoecus, only scanning electron microscopy (SEM) studies of papillar distribution were published (Caira 1989, Moravec 2002). In other species of Crepidostomum, the distribution of papillae was observed by SEM by Caira (1989), Choudhury and Nelson (2000) and Moravec (2002).

Papillae of different species of adult digeneans were followed mainly with SEM (e.g. by Bennett 1975b, Sakamoto and Ishii 1977, Bakke 1978, Font and Wittrock 1980, Crites and Jilek 1981, Žd'árská et al. 1983, 1988, Žd'árská and Soboleva 1990). With TEM, the structure of the papillae of adult digeneans was studied by Bennett (1975a) in Fasciola hepatica Linnaeus, 1758; Edwards et al. (1977) in Philophthalmus megalurus (Cort, 1914); Fujino et al. (1979) in Clonorchis sinensis (Cobbold, 1875); Hoole and Mitchell (1981) in Gorgoderina vitelliloba (Olson, 1876); Dunn et al. (1987) in three species of paramphistomes, and Žd'árská (1993) in Brachylaimus aequans (Looss, 1899).

\section{MATERIALS AND METHODS}

Specimens of Crepidostomum metoecus were removed from the intestine of Salmo trutta fario L. collected in the Czech Republic (Homolský Brook in Velké Březno, northern
Bohemia). Five samples were washed in saline, fixed in 3\% glutaraldehyde in $0.1 \mathrm{M}$ sodium cacodylate buffer $(\mathrm{pH} 7.2)$ for $2 \mathrm{~h}$ at $4^{\circ} \mathrm{C}$, postfixed for $2 \mathrm{~h}$ at $4^{\circ} \mathrm{C}$ in $1 \%$ osmium tetroxide, dehydrated through an ethanol series and embedded in Durcupan via acetone. A series of ultrathin sections were cut using a Leica UCT ultramicrotome, double-stained with uranyl acetate and lead citrate and viewed in a JEOL 1010 transmission electron microscope operated at $80 \mathrm{kV}$. Semithin sections were stained in toluidine blue.

\section{RESULTS}

Five types of presumed ciliate sensory receptor were detected in the forebody papillae of Crepidostomum metoecus (Fig. 1).

\section{Type I receptor}

Figs. 2, 12A

The bulb of the receptor, localised in the proximal part of the papilla, is attached at the apical projection to the tegument by a septate junction. The septate junction connects the neurilemma at the level of the electrondense collar to the tegument basal plasma membrane, supported at this site, by an electron-dense cytoplasmic plaque. The basal body lies in the projection of the apical part of the bulb. The proximal part of the bulb contains a concentrated array of neurotubules and the distal part mitochondria. The cilium (800-900 nm long) is submerged into a pit.

\section{Type II receptor}

Figs. 3-5, 12B

The bulb of the receptor possesses a basal body, a long, narrow, cross-striated rootlet, membraneous body, mitochondria and neurotubules, located mainly in the basal part and in the dendrite. The apical projection of the bulb surrounding the basal body is supported by an electron-dense collar. An electron-dense cytoplasmic 


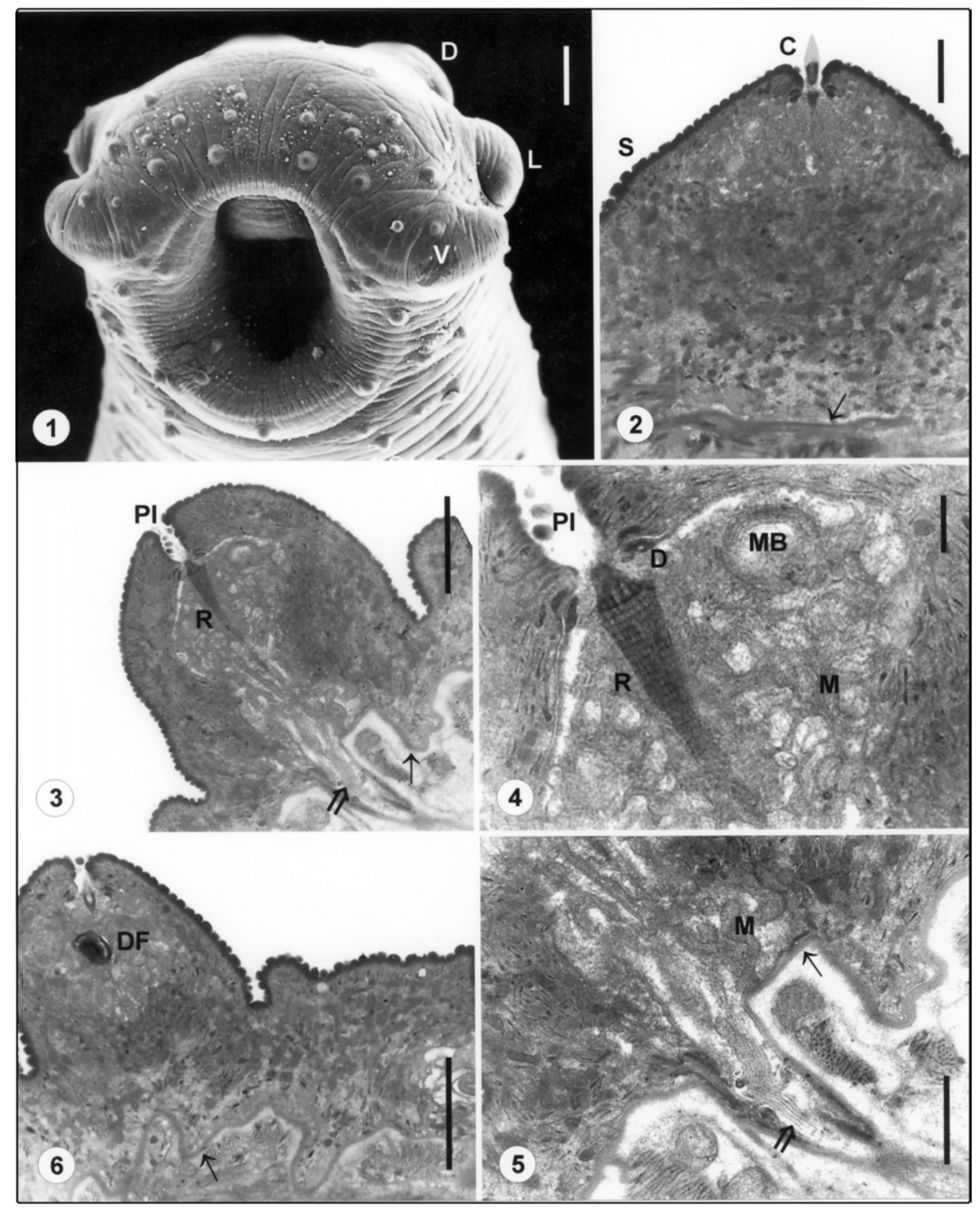

Figs. 1-6. Sensory receptors in forebody papillae of Crepidostomum metoecus, scanning and transmission electron micrographs. Fig. 1. Distribution of papillae on the forebody. V - ventral, L - lateral and D - dorsal oral lobes. Fig. 2. Vertical section of papilla with sensory receptor type I with a short cilium (C), a dense collar and basal body. S - tegument surface tubercles; arrow - basal lamina. Fig. 3. Longitudinal section of a papilla with type II sensory receptor. The bulb contains a long narrow crossstriated rootlet $(\mathrm{R})$; a dendrite (double arrow) penetrates between circular muscle fibres. PI - pit of tegument with surface tubercles (the cilium is out of section); arrow - basal lamina. Fig. 4. Detail of Fig. 3. R - cross-striated rootlet; MB - membranous body; M - mitochondria; D - dense collar; PI - pit of tegument. Fig. 5. Detail of Fig. 3. The dendrite (double arrow) contains neurotubules. M - mitochondria; arrow - basal lamina. Fig. 6. Tangential section of a papilla with sensory receptor type III. The central part of the bulb contains a dense formation (DF). The apical part is supported by a dense collar at the level of the basal body of a short cilium. Arrow - basal lamina. Scale bars: Fig. $1=20 \mu \mathrm{m}$; Figs. 3, $6=2 \mu \mathrm{m}$; Figs. 2, $5=1 \mu \mathrm{m}$; Fig. $4=400$ nm. 


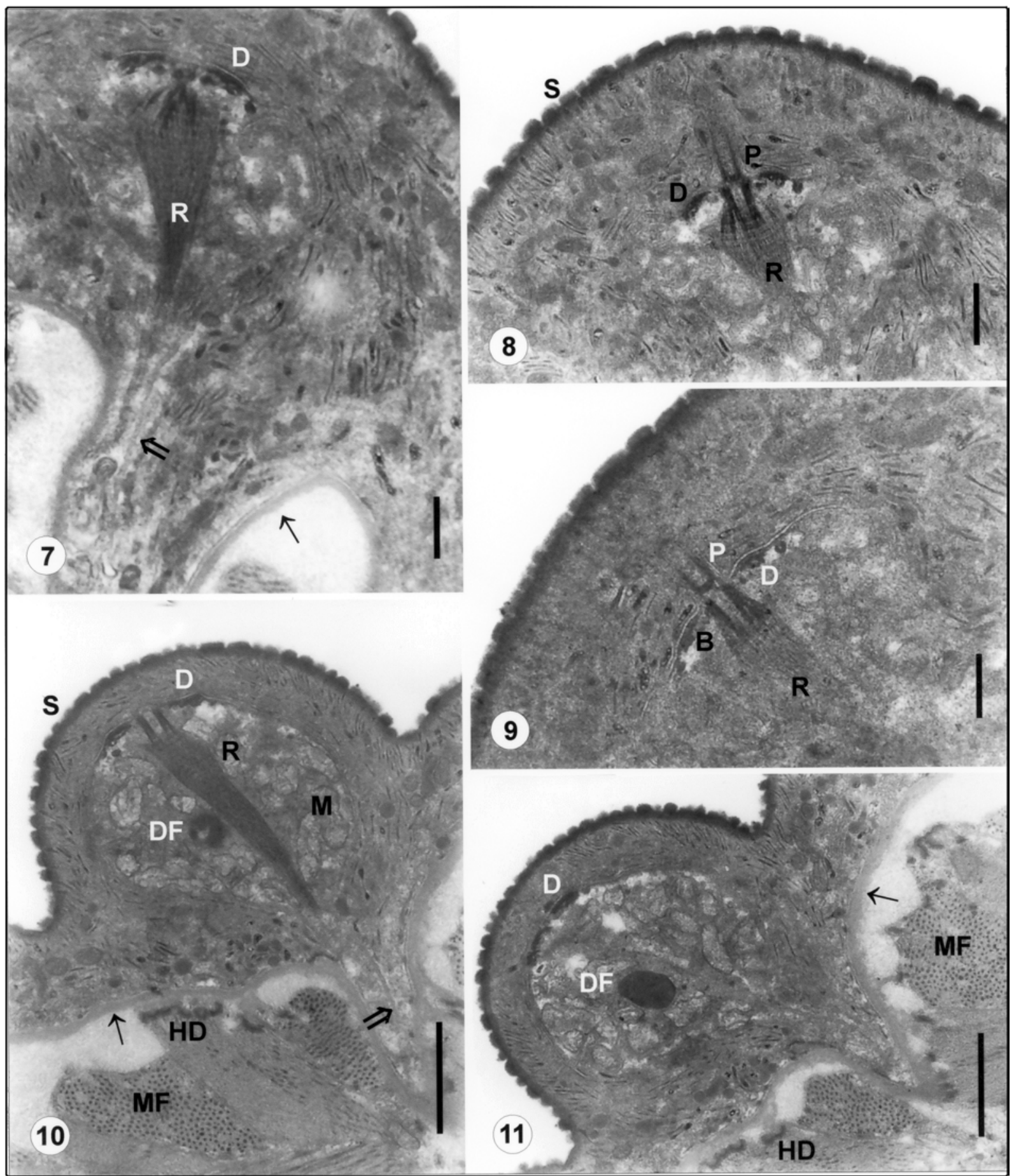

Figs. 7-11. Sensory receptors in papillae of Crepidostomum metoecus, transmission electron micrographs. Fig. 7. Tangential section of a papilla with sensory receptors type IV. The bulb contains a large, long, cross-striated rootlet (R). Radial electrondense fibres cover the rootlet forepart. The bulb is supported by a large dense collar (D). Below the collar there is a circle of scattered dense material. Double arrow - dendrite; arrow - basal lamina. Fig. 8. Serial section to Fig. 7. R - forepart of crossstriated rootlet with radial electron-dense fibres distal to the basal body. Proximal to the basal body there is the basal plate (P) of the cilium. Below the collar (D) there are parts of scattered dense material. S - tegument surface tubercles. Fig. 9. Tangential section of a papilla with sensory receptor type $\mathrm{V}$ with a long, weakly striated rootlet (R), dense formation (DF), mitochondria (M) and dense collar (D) with scattered dense material below it. Double arrow - dendrite; arrow - basal lamina; HD hemidesmosomes; MF - muscle fibres; $\mathrm{S}$ - tegument surface tubercles. Fig. 10. Serial section to Fig. 9. Papilla with sensory receptor type V. P - basal plate of cilium; B - basal body; R - rootlet; D - dense collar with parts of scattered dense material below it. Fig. 11. Serial section to Fig. 9. D - dense collar; DF - dense formation; MF - muscle fibres; HD hemidesmosomes; arrow - basal lamina. Scale bars: Figs. 7, 8, $10=400 \mathrm{~nm}$; Figs. 9, $10=1 \mu \mathrm{m}$. 

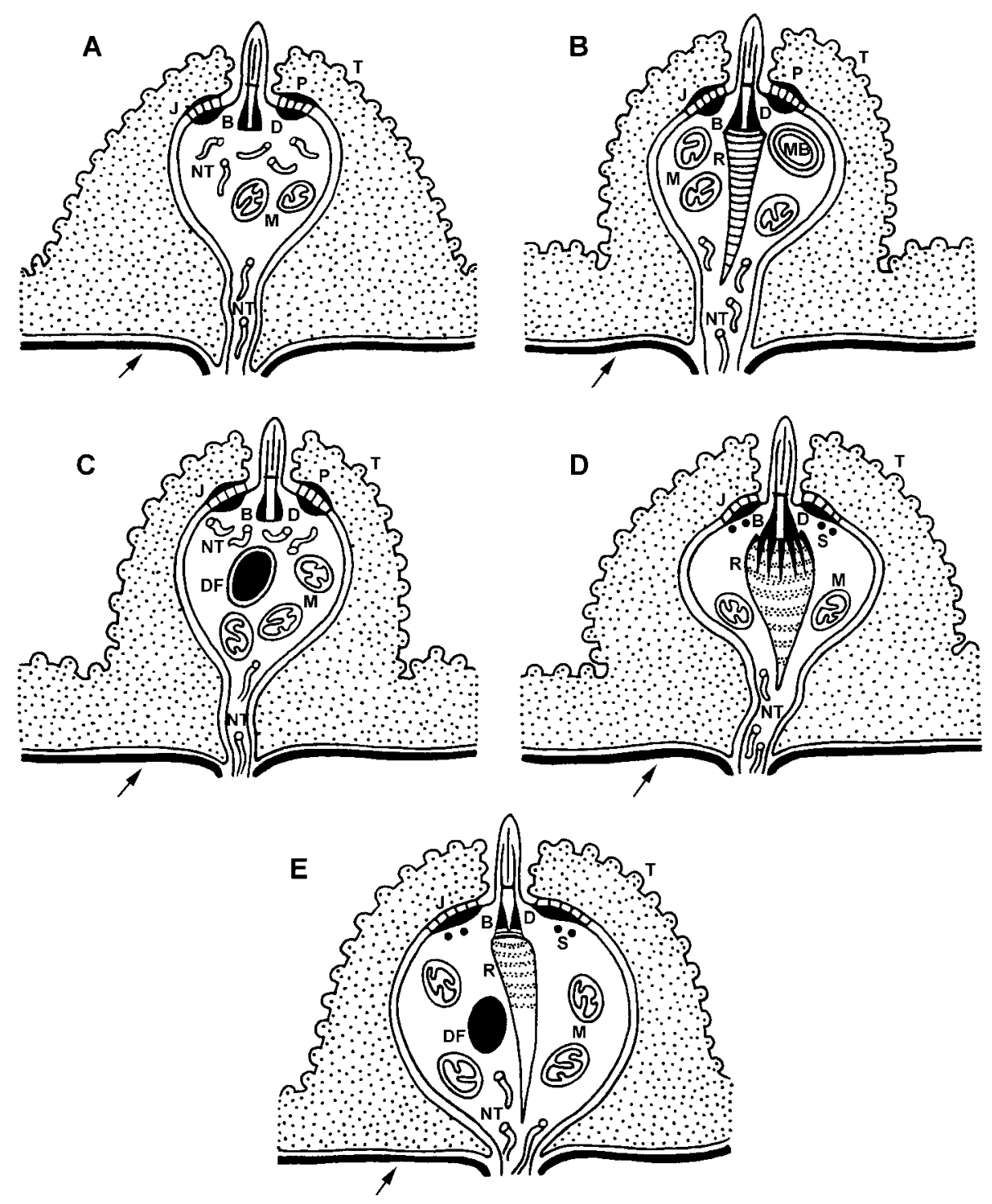

Fig. 12. Diagrams of intra-papillar uniciliate sensory receptors of Crepidostomum metoecus. A - type I receptor; $\mathbf{B}$ - type II receptor; C - type III receptor; D - type IV receptor; $\mathbf{E}$ - type V receptor. Explanation of abbreviations: B - basal body; D dense collar; F - dense formation; J - septate junction; NT - neurotubules; M - mitochondria; MB - membranous body; P cytoplasmic plaque; $\mathrm{R}$ - rootlet; $\mathrm{S}$ - scattered electron dense material; $\mathrm{T}$ - tegumental tubercles; arrow - basal lamina.

plaque is opposite to the collar. Both electron-dense formations are connected by a septate junction. The short cilium is submerged to a tegumental pit bearing surface tubercles.

\section{Type III receptor}

Figs. 6, 12C

This type of sensory receptor partly corresponds with the type I receptor. The main difference is the presence of a dense formation $(700 \times 400 \mathrm{~nm})$ in the central part of the bulb. In the apical part, around the basal body, there are concentrations of neurotubules. The apical projection of the bulb is supported by an electron-dense collar. Opposite to the collar is an electron-dense cyto- plasmic plaque at the tegument basal plasma membrane. A short cilium is submerged to the tegumental pit bearing surface tubercles.

\section{Type IV receptor}

Figs. 7, 8, 12D

The bulb of this receptor possesses a long $(1.6 \mu \mathrm{m})$ cross-striated rootlet. The rootlet forepart $(700 \mathrm{~nm}$ in width) is covered by radially-arranged electron-dense fibres. The bulb is supported by a large electron-dense collar but without an electron-dense cytoplasmic plaque as in types II and III. Below the collar there is a circle of scattered electron-dense material. The bulb contains small electron-lucent vesicles, mitochondria and neuro- 
tubules, located mainly in the basal part and in the dendrite. The short cilium is submerged into a tegumental pit.

\section{Type $V$ receptor}

Figs. 9-11, 12E

The bulb of the receptor contains a long, narrow, feebly cross-striated rootlet $(2 \times 0.4 \mu \mathrm{m})$, a dense formation $(300 \times 500 \mathrm{~nm})$, mitochondria and neurotubules. The apical part of the bulb is supported by a large dense collar; as in type IV receptor, an electron-dense cytoplasmic plaque is not present. Bellow the collar there is scattered electron-dense material. A short cilium is submerged into a tegumental pit.

\section{DISCUSSION}

This ultrastructural study of Crepidostomum metoecus includes only observations on presumed sensory receptors found in muscular forebody papillae. The structure of the intra-tegumental sensory receptors of this species, located in the basal part of the tegument, has been described earlier (Žd'árská and Nebesářová 2003b). In the forebody papillae of this digenean, only ciliate sensory receptors were detected. Non-ciliate intra-papillar receptors reported for other digeneans (Bennett 1975a, Fujino et al. 1979, Hoole and Mitchell 1981, Dunn et al. 1987, Žd'árská 1993) were not present.

In C. metoecus, only a ciliate intra-papillar receptor (type I) resembles the intra-tegumental ciliate type I receptor described earlier (Žd’árská and Nebesářová 2003b). The intra-papillar receptor differs only in the cytoplasmic plaque above the septate junction, which in the intra-tegumental receptor is less developed.

In $C$. metoecus, two types of intra-papillar ciliate receptors (type III and type IV) contain a dense forma- tion. Dense formations were observed earlier in nonciliate receptors of the digeneans Clonorchis sinensis by Fujino et al. (1979) and Gorgoderina vitelliloba by Hoole and Mitchell (1981). Electron-dense formations (of different shape and dimensions) have been observed in other platyhelminths in ciliate and non-ciliate sensory receptors. Rohde and Watson (1990) detected a dense formation in a non-ciliate receptor of larval aspidogastrid Multicotyle purvisi Dawes, 1941; Bruňanská et al. (2000) in a ciliate receptor (type VII) in preadult cestode Proteocephalus longicollis (Zeder, 1800) and Žd'árská and Nebesáŕová (2003a) in a non-ciliate receptor of adult cestode Silurotaenia siluri (Batsch, 1786). The significance of electron-dense formations in sensory receptors is unknown. It is possible that these formations are products of some degenerative processes or have some special functions. The ciliate sensory receptors located in the forebody muscular papillae of C. metoecus are either mechano- or chemoreceptors, or have a combined mechano- and chemoreceptive functions. The distribution of the forebody muscular papillae, associated with different types of receptors (found mainly on the frontal part of the oral sucker), shows the important role of the anterior end in the interaction with the environment. It is possible that the receptors located in papillae are involved in mechanisms associated with the attachment of the trematode to a specific site of the host.

Acknowledgements. We wish to thank Dr. F. Moravec for collecting the parasites. We also appreciate the technical assistance of Mrs. B. Škoríková, Mr. A. Polák, Mrs. L. Nováková and Mrs. P. Masařová. This study was supported by the Grant Agency of the Czech Republic, project no. 524/00/0267 and the Institute of Parasitology, Academy of Sciences of the Czech Republic, research project AV0Z6022909.

\section{REFERENCES}

BAKKE T.A. 1978: Urogonimus macrostomus (Rudolphi, 1803) (Digenea): its taxonomy and morphology as revealed by light and scanning electron microscopy. Can. J. Zool. 56: 2280-2291.

BENNETT C.E. 1975a: Surface features, sensory structures and movement of the newly excysted juvenile Fasciola hepatica L. J. Parasitol. 61: 886-891.

BENNETT C.E. 1975b: Scanning electron microscopy of Fasciola hepatica L. during growth and maturation in the mouse. J. Parasitol. 61: 892-898.

BRUŇANSKÁ M., FAGERHOLM H.-P., GUSTAFSSON M.K.S. 2000: Ultrastructure studies of preadult Proteocephalus longicollis (Cestoda, Proteocephalidae): transmission electron microscopy of scolex sensory receptors. Parasitol. Res. 86: 89-95.

CAIRA J.N. 1989: A revision of the North American papillose Allocreadiidae with independent cladistic analyses of larval and adult forms. Bull. Univ. Nebraska State Mus. 11: $1-58+195$ figs.
CHOUDHURY A., NELSON P.A. 2000: Redescription of Crepidostomum opeongoensis Caira, 1985 (Trematoda: Allocreadiidae) from fish hosts Hiodon alosoides and Hiodon tergisus (Osteichthyes: Hiodontidae). J. Parasitol. 86: 1305-1312.

CRITES J.L., JILEK R. 1981: Surface topography of Hasstilesia tricolor (Trematoda: Brachylaemidae) as demonstrated by scanning electron microscopy. Ohio J. Sci. 81: 120 124.

DUNN T.S., HANNA R.E.B., NIZAMI W.A. 1987: Ultrastructural and cytochemical observations on the tegument of three species of paramphistomes (Platyhelminthes: Digenea) from the Indian water buffalo, Bubalus bubalis. Int. J. Parasitol. 17: 1153-1161.

EDWARDS H.H., NOLLEN P.M., NADAKAVUKAREN M.J. 1977: Scanning and transmission electron microscopy of oral sucker papillae of Philophthalmus megalurus. Int. J. Parasitol. 7: 429-437. 
FONT W.F., WITTROCK D.D. 1980: Scanning electron microscopy of Leucochloridiomorpha constantiae during development from metacercaria to adult. J. Parasitol. 66: 955-964.

FUJINO T., ISHII Y., CHOI D.W. 1979: Surface ultrastructure of the tegument of Clonorchis sinensis newly excysted juveniles and adult worms. J. Parasitol. 65: 579590.

HOOLE D., MITCHELL J.B. 1981: Ultrastructural observations on the sensory papillae of juvenile and adult Gorgoderina vitelliloba (Trematoda, Gorgoderidae). Int. J. Parasitol. 11: 411-417.

MORAVEC F. 2002: External morphological differences between Crepidostomum farionis and Crepidostomum metoecus (Trematoda: Allocreadiidae), parasites of salmonids, as revealed by SEM. Folia Parasitol. 49: 211-217.

ROHDE K., WATSON N. 1990: Non-ciliate sensory receptors of larval Multicotyle purvisi (Trematoda, Aspidogastrea). Parasitol. Res. 76: 585-590.

SAKAMOTO K., ISHII Y. 1977: Scanning electron microscope observations on adult Schistosoma japonicum. J. Parasitol. 63: 407-412.

ŽĎÁRSKÁ Z. 1993: Transmission electron microscopy of ventral sucker papillae of Brachylaimus aequans (Digenea: Brachylaimidae). Folia Parasitol. 40: 203-207.
ŽĎÁRSKÁ Z., BAKKE T.A., SOBOLEVA T.N. 1988: Scanning electron microscopy of the trematode Brachylaimus aequans (Looss, 1899). Folia Parasitol. 35: 277-279.

ŽĎÁRSKÁ Z., NEBESÁŘOVÁ J. 2002a: Ultrastructure of pigmented photoreceptor of adult Crepidostomum metoecus (Trematoda: Digenea: Bunoderidae). Folia Parasitol. 49: 165-166.

ŽĎÁRSKÁ Z., NEBESÁŘOVÁ J. 2002b: Ultrastructure of the forebody and foregut tegument and eccrine gland cells of Crepidostomum metoecus (Trematoda: Digenea: Allocreadiidae). Folia Parasitol. 49: 291-294.

ŽĎÁRSKÁ Z., NEBESÁŘOVÁ J. 2003a: Ultrastructure of the early rostellum Silurotaenia siluri (Batsch, 1786) (Cestoda: Proteocephalidae). Parasitol. Res. 89: 495-500.

ŽĎÁRSKÁ Z., NEBESÁŘOVÁ J. 2003b: Transmission electron microscopy of the intra-tegumental sensory receptors of Crepidostomum metoecus (Digenea: Allocreadiidae). Folia Parasitol. 50: 215-219.

ŽĎÁRSKÁ Z., SOBOLEVA T.N. 1990: Scanning electron microscopic investigation of the trematode Hasstilesia ochotonae Gvosdev, 1962. Folia Parasitol. 37: 347-348.

ŽĎÁRSKÁ Z., SOBOLEVA T.N., BAKKE T.A. 1983: Scanning electron microscopy of the trematode Hasstilesia ovis. Folia Parasitol. 30: 341-344.

Accepted 15 December 2003 